Kokhan Olena,

Senior Lecturer, Kyiv National University of Trade and Economics, 19, Kyoto str., Kyiv, 02156, Ukraine ORCID: 0000-0003-4582-0814, Researcher ID: B-8885-2019

\title{
FOREIGN LANGUAGE LEARNING BASED ON ICTs
}

The article discusses the use of information and communication technologies (ICTs) and their achievements in the foreign language learning. Using ICT in a foreign language lesson provides an imitation of a foreign language environment, creates the conditions for authentic communication, increases motivation to learn a foreign language and intensifies the development of such skills as reading, writing, speaking, perception of a foreign language. The article analyzes and presents links to resources for teaching and learning English and other foreign languages. The author also notes the effectiveness of software applications for independent learning of a foreign language.

Keywords: information and communication technology (ICT), social media, interactive teaching, blogs, language-learning apps.

\section{Кохан Олена. Вивчення іноземної мови на основі ІКТ.}

У статті розглядається питання використання інформачійно-комунікаційних технологій (IКT) та їх результативність при вивченні іноземних мов. Використання IКТ на занятті з іноземної мови забезпечує імітацію іншомовного середовища, створюе умови для автентичного спілкування, підвищує мотивацію до вивчення іноземної мови та активізує розвиток таких навичок як читання, письмо, говоріння, сприйнятття іноземної мови. У статті проаналізовано та подано посилання на ресурси для викладання та вивчення англійської та інших іноземних мов. Автор також зазначає ефективність програмних додатків для самостійного вивчення іноземної мови.

Ключові слова: інформаційно-комунікачійні технології (IКT), соиіальні медіа, інтерактивне навчання, блоги, програмні додатки для вивчення мов.

Relevance of research topic. The rapid entry of Ukraine into the world market and the European space, the informatization and computerization of society require a person with new knowledge, skills that will be adapted to the conditions of the 
information society. The processes taking place in connection with the informatization of society contribute not only to the acceleration of scientific and technological progress, but also to the creation of a qualitatively new information environment of the society, which ensures the development of the individual's creative potential. One of the priorities of the modern society is the informatization of education, which is to use of a rational combination of traditional educational technologies and modern ICT. Since knowledge of a foreign language has become practical necessity for a modern educated person, it is the introduction of innovative teaching methods that will help future specialists to improve the quality of their foreign language skills.

Formulation of the problem. Traditional pedagogical technologies for teaching foreign languages are limited in the ability to simulate a foreign language environment, take into account the individual differences of students and create conditions for genuine communication in the language being studied. Therefore, pedagogy includes computer and telecommunication equipment in the educational process and develops methods for its application. Using ICT in a foreign language lesson provides an imitation of a foreign language environment, creates the conditions for authentic communication, increases motivation to learn a foreign language and intensifies the development of specific skills.

Analysis of recent researches and publications. Recently, there has been a significant increase in the number of studies focusing on the use of ICT in the educational process. In Ukraine this topic is highlighted in the researches of such scientists as V. Bykov, Ya. Bulakhova, O. Bondarenko, V. Zabolotny, G. Kozlakova, O. Mishchenko, O. Pinchuk and others. E. Polat, E. Dmitryeva, S. Novikov, T. Polilov, L. Tsvetkova are actively engaged in the development and implementation of new ICTs in the educational process. P.Sysoev, M. Evstigneev have contributed to creation of author's Internet resources in a foreign language.

Presenting main material. Information and communication technology, usually abbreviated as ICT, is often used as an extended synonym for information technology (IT), but is usually a more general term that stresses the role of unified communications and the integration of telecommunications (telephone lines and wireless signals), computers, middleware as well as necessary software, storageand audio-visual systems, which enable users to create, access, store, transmit, and manipulate information. ICT refers to technologies that provide access to information through telecommunications. It is similar to Information Technology (IT), but focuses primarily on communication technologies. This includes the internet, wireless networks, cell phones, and other communication mediums. (Bykov V., 2012)

In the past few decades, information and communication technologies have provided society with a vast array of new communication capabilities. For example, people can communicate in real-time with others in different countries using technologies such as instant messaging, voice over IP (VoIP), and video-conferencing. Social networking websites like Facebook allow users from all over the world to 
remain in contact and communicate on a regular basis. Modern information and communication technologies have created a «global village», in which people can communicate with others across the world as if they were living next door. For this reason, ICT is often studied in the context of how modern communication technologies affect society. Nowadays the role of ICT, especially the Internet in the education sector plays an important role, especially in the process of empowering the technology into the educational activities. Technology (internet) can be the most effective way to increase the student's knowledge. ICT is not just the bloom of the educational activities, but also it will be the secondary option to improve the effective and meaningful educational process. The main purpose of the Strategy for Information and Communication Technology Implementation in Education is to provide the prospects and trends of integrating ICT into the general educational activities. Researchers show that the most important achievements of ICT are the following :

- enhance learning opportunities through access to a range of resources, stimulus materials and learning tools;

- provide increased opportunities for student engagement and motivation;

- equip students with the necessary knowledge and skills to use ICT to support 21st-century learning;

- support the development of effective student research and evaluation skills;

- promote critical and creative thinking skills;

- increase teacher and student efficiency;

- develop awareness of the public nature of online activity and related responsibilities;

- increase opportunities to work collaboratively, locally, nationally and globall. (Houcine S., 2011)

Use of information technology significantly improves quality of visual and audio information, it becomes brighter, more dynamic, that is, lighter to be remembered. Classes using information technology designed for practicing practical skills and self-employed skills, control and self-control. The main and crucial advantage of IT compared to all other learning aids is the possibility of creating a language training environment that is authentic and the intensity of language communication close to real communication, what could not be reached earlier. The next most important point on the benefit of using informational technologies in the study of foreign languages can be considered constructive conditioned individualized nature of learning that is especially important with presence of listeners with different initial levels of language proficiency, varying degrees of motivation and level of skills.

Using ICT gives the learners real-life contact with the culture of people and countries where the new language is spoken, provides access to the information worldwide. ICT, in particular email, blogs and video conferencing, facilitates interaction and communication with native speakers and other communities by enabling students to use language for real purposes and in real contexts. ICT both 
supports and integrates literacy skills. It enhances interactive teaching and learning styles and provides many opportunities for creativity. When used imaginatively it can stimulate curiosity about how languages work, raise the level of cognitive challenge, and extend students' ability to be independent in their use of the new language. ICT offers a powerful way to be fully engaged in its own language learning process. Tasks done at home, at university or on a trip abroad can be uploaded to a learning platform, enabling teachers, students to make comments and celebrate achievements. Through the use of a learning platform, ICT can supplement training programmes to help ensure that support is maintained over the coming years as increasing numbers of teachers are trained to teach a new language at primary level. Interactive whiteboards, DVDs and the use of digital projectors can provide stimulating visual aids as a valuable strategy to support understanding and recall in the new language. ICT has the potential to increase the percentage of learning that involves the traditionally more difficult literacy skills by maximizing exposure to the written word.

The sites of the British Council and BBC services provide a wide range of practical resources for teachers and learners. All activities, as well as ideas for using songs, poems and stories help learners improve their English in engaging, motivating and enjoyable ways:

- learnenglish.britishcouncil.org/en;

- www.bbc.co.uk/worldservice/learningenglish.

From reference books to a pronunciation guide teachers and students will get a lot of use out of these links. Dictionary.com also offers translation, a word of the day, games, quotes. Thesaurus.com: goes beyond simple reference, bringing inspiration and fun in the form of synonyms, fun word facts, and even search trends. Idiom Site: with the help of this site English language learners can make sense of common idioms. Fonetiks: direct students to useful pronunciation guide with instant sound and samples by native speakers. (Spivakovs'ka Ye.O., 2012)

The Internet supplies very popular dictionaries which are freely available for users from all over the world. They located on the following sites: www.ldoceonline.com (online version Longman Dictionary of Contemporary English); www.dictionary. cambridge.org (online version of the Cambridge Dictionary).

Exercises for mastering vocabulary and grammar, training programs, various projects as well as forums for teachers where there is an opportunity to exchange experiences are located at: www.globalschoolnet.org; www.onestopenglish.com; www.foreign-languages.com.

Those who want to test their knowledge can turn their attention to sites:

www.TestYourEnglish.net; www.English-test.net; www.toefl.org; www.ielts.org.

Social media is a way to write about ourselves and interact with others. There are lots of different types of social media: social networking sites, online forums, sharing photos and videos, writing reviews, blogs. Social media is basically a structure 
that consists of individuals, communities, companies or organizations with similar interests, attitudes, values, lifestyles, visions and friendships and in the field of eLearning this structure can be used in various ways and through a number of tools. The most popular ones:

Facebook. The instructor can effortlessly create a closed or an open group, to share information, ideas, quizzes, questionnaires, materials, pictures, or even an entire page on a specific course or module. Students can freely talk about various courserelated issues, questions they might have, post mutually interesting information and generally things they want to share. The Cambridge Assessment English Facebook page is updated every day, giving regular opportunities to practice English.

Twitter. In eLearning it can be used as a backchannel to connect learning communities or smaller classrooms over a specific topic or event, to share highlights, make statements, upload pictures, etc.

LinkedIn. This is a purely professional, yet still social network, which has proven to be extremely useful in eLearning. Currently there are thousands of discussions and groups in various languages, where instructors, educators and influencers share views, problems, developments and how-to tips. Students/ participants can see everyone's professional profile and accomplishments, something that usually determines the status of the discussion leader, organizer, or expert.

Communities and blogs provide help and regular feedback for ELL : Learning the Language; Englishtown; ESL Podcast: ESL Resource Center; Teacher Talk; Pain in the English; TEFL tastic with Alex Case; The English Blog.

In addition to a wide variety of the Internet resources, there are a large number of computer programs for learning English. Language learning apps help ELL learn and study languages at their own pace. You can work through lessons from the comfort of your home or during your commute on a mobile app. Some programs focus on helping you understand and speak a new language, while others are better for reading and writing. Some help you build a foundation for a lifetime of learning, some just teach travel phrases. (Brian T., Whittaker C., 2013)

The best free language-learning app is Duolingo. It is available as both a web app and mobile app, and it works well whether you're a total beginner or already have some experience. Users can take a placement test to find the right place to start. Among paid language-learning apps, Rosetta Stone is the best. It's reliable, accurate, and it offers programs for 28 languages (excluding English). Each lesson takes around 30 minutes to complete, and even if you do one lesson per day, there's enough content to keep you busy for months.

Language-learning software programs are self-paced and sometimes even selfdirected. Not everyone thrives in such an independent learning environment, however. If you like to have a teacher who explains the language to you, Fluenz is a wonderful option. 
Conclusion. Without a doubt, ICT is a valuable and an innovative teaching tool enhancing EFL learning. The rapid growth of ICT has naturally influenced the every aspects of language teaching process. Using technology has positive effects on teaching and learning English. Technology can be applied to teaching practices to enhance and facilitate foreign language learning. Computer, Internet, smart boards, cell phones, video games, music players are used in the target language learning process to raise students' motivation and language awareness. ICT makes English language environment interactive, flexible and innovative. The application of computer technologies in language instruction provides a student-centred learning environment.

\section{REFERENCES}

1. Brian T. (2013). Whittaker C. Blended Learning in English Language Teaching: Course Design and Implementation // British Council. - P. 252.

2. Bykov V. (2012). Problemy ta perspektyvy informatyzatsiyi systemy osvity v Ukrayini // Naukovyy chasopys NPU imeni M. P. Drahomanova. Seriya 2 : Komp'yuterno-oriyentovani systemy navchannya. - № 13.

3. Houcine S. (2011). The effects of ICT on learning/teaching in a foreign language. Retrieved from: https://conference.pixel-online.net/conferences/ICT4LL2011/ common/download/Paper_pdf/IBL69-437-FP-Houcine-ICT4LL2011.pdf

4. Spivakovs'ka Ye.O. (2013). Vykorystannya novykh informatsiynykh tekhnolohiy u vyvchenni studentamy anhliys'koyi movy// Informatsiyni tekhnolohiyi v osviti. № 15. S. 222-228. Retrieved from: http://ite.kspu.edu/webfm_send/478 